\title{
Quantification, Variability Assessment of Bacterial Pollution and Public Health Hazards Linked to Users of Automated Teller Machines in Ekpoma, Edo State-Nigeria
}

\author{
Osatohanmwen Osarenmwinda ${ }^{*}$, Omoike Ofure Blessing \\ Department of Microbiology, Faculty of Life Sciences, Ambrose Alli University, Ekpoma, Nigeria \\ Email address: \\ osas.sato@gmail.com (O. Osarenmwinda),omoikeblessing0@gmail.com (O. O. Blessing) \\ ${ }^{*}$ Corresponding author
}

\section{To cite this article:}

Osatohanmwen Osarenmwinda, Omoike Ofure Blessing. Quantification, Variability Assessment of Bacterial Pollution and Public Health Hazards Linked to Users of Automated Teller Machines in Ekpoma, Edo State-Nigeria. International Journal of Microbiology and Biotechnology. Vol. 5, No. 1, 2020, pp. 34-40. doi: 10.11648/j.ijmb.20200501.16

Received: February 5, 2020; Accepted: February 21, 2020; Published: March 2, 2020

\begin{abstract}
Raising number of mortals has used automated teller machines (ATMs) over the years, but little is known about their microbial colonization status. Based on this premise, we examined eight out of the nine commercial bank's ATM in Ekpoma environs for quantification, variability assessment of the bacterial cross contamination and the likely health hazards linked to the users of such cash dispensing machines. A total number of sixteen (16) samples were acquired from eight different commercial banks ATM keypads and screens within the study area, using sterile swab sticks immersed in sterile normal saline. Samples were subsequently transferred to the laboratory section of the Department of Microbiology, Faculty of Life Sciences, Ambrose Alli University, Ekpoma for analyses using standard microbiological procedures for isolation, quantification and identification between the period of September to October 2019. Results showed that the total aerobic bacteria count, Staphylococcus aureus and coliforms counts on both the ATM keypads and Screens ranged from $9.0 \times 10^{3} \pm 2.65 \mathrm{cfu} / \mathrm{m}^{2}$ to $1.92 \times 10^{4} \pm 3.61 \mathrm{cfu} / \mathrm{m}^{2}, 3.5 \times 10^{3} \pm 1.73 \mathrm{cfu} / \mathrm{m}^{2}$ to $9.8 \times$ $10^{3} \pm 4.58 \mathrm{cfu} / \mathrm{m}^{2}$ and $4.8 \times 10^{3} \pm 1.00 \mathrm{cfu} / \mathrm{m}^{2}$ to $1.08 \times 10^{4} \pm 2.00 \mathrm{cfu} / \mathrm{m}^{2}$ respectively. One-way Anova depicted a no significant difference $(\mathrm{P}>0.05)$ in the total aerobic bacterial plate count, Escherichia coli and Staphylococcus aureus counts in the various banks' ATM keypads and screens in respectively of the facilities placement and the number of users. The bacteria implicated in this study were Escherichia coli, Bacillus spp, Klebsiella pnuemoniae, Staphylococcus aureus, Pseudomonas aeruginosa, Proteus spp and Coagulase negative Staphylococcus spp. The findings from this study reveals that high volume of bacterial pollution were detected on ATM hardware user interface which invariably necessitated the need for adequate personal hygiene by both the users and custodians of such machines with a view to reducing the likely hood of spreading contagious agents.
\end{abstract}

Keywords: Microorganisms, Automated Teller Machines (ATM), Public Health, Cross-Contamination and Pathogenic Bacteria

\section{Introduction}

An automated teller machine (ATM) is a device that operates on the principles governing the behavior of electrons used for broadcasting messages over a length electronically. It allows clients of these money institutions (Banks) to carryout transactions, such as the transfer of funds, cash withdrawals, money deposits or acquiring account information and record, round the clock (twenty four hours every day) with little or no direct physical assistance from a bank personnel [1]. These machines are the longest standing and most widely operated form of computer use by the general public giving comfort to customers [2]. The ATM can also be called to as a public place device because of the large number of people that makes use of this machine daily especially in metropolitan areas [3]. ATMs are also known as cash dispenser, ATM machine, automated banking machine, cash machine, etc. 
by different people in various parts of the world. Using the ATM involves insertion of the ATM card into a receiver hole on the machine, following display guidelines onscreen, pressing the keys of the metallic keypads to input secret codes and commands; thus giving directives to the machine with respect to the kind of service one intend to execute [4]. The ATM comprises of a computer with a white or silvered surface where pictures can be projected for viewing (screen) and a device for data imputation (keypad) to access bank accounts through a host processor, telephone networking, and a bank computer to authenticate data. Physical presence of the bank customer is needed to perform any financial transactions [5]. Thus providing an avenue for high human dermal contact which could be a source of contamination, infections and health hazard to man. Microorganisms are biological entities that are so minute in such a way that they can't be seen with the naked eye but with the microscope, they include bacteria, yeasts, viruses, moulds, algae and protozoa. Microorganisms are found in all places in the environment, and are in high number in the air, soil, water, food and various human body parts [6]. They are able to exist or even grow on surfaces [7]. Although most of them are harmless, some are capable of causing diseases especially in people whose body defense system has been compromised. The ATM is likely to be contaminated with many different forms of microorganisms both harmful and harmless due to the frequent ways in which they are being used [8]. Bacteria that can cause severe gastroenteritis have also been isolated on the ATM keypads [9]. ATM once contaminated becomes a medium for the transmission of infection, in such a way that the user might end up picking up these pathogens after making use of the machine, since there is no confinement as to who makes use of these machines, and no guidelines to ensure hygienic usage [10]. Also, the poor environment in which these machines are kept may have an impact on the service quality provided by this machine apart from the health concerns they are likely to pose [11]. Contamination of surfaces and objects in the environment is not unknown of and humans certainly has a high probability of picking up microorganisms from environmental objects (fomites) with the hands playing a vital part in the transmission of these organisms [12] and the raising frequency of occurrence of antimicrobial immunity by many virulent microbes, thus the focus of public health management is now tinted towards disease prevention as against treatment. Some researchers before now have tried to probe the quality and environmental pitfalls linked with the computers in health facilities and other public arena from the view point of environmental hygiene in qualitative and quantitative terms. Little or nothing has been done about the study of ATMs in Ekpoma and its environs with respect to environmental quality assessment of virulent microbial contaminations this study therefore is geared towards assessing commercial banks' ATMs in Ekpoma for bacterial contamination.

\section{Materials and Methods}

\subsection{Study Area}

This assessment was done in Ekpoma environs domiciliated in Esan-West Local Government Area of Edo State. It has an area of $502 \mathrm{~km}^{2}$ with about 190,000 people who comprise an adult male population of over 60,000 and adult female population of 50,000 respectively. It lies on a geographical coordinate of latitude $6^{\circ} 45^{\prime} \mathrm{N} 6^{\circ} 08^{\prime} \mathrm{E}$ and has an elevation of approximately 364 meters above sea level [13].

\subsection{Samples Acquisition and Processing}

Verbal permission was obtained from the banks' security personnel. A total of sixteen (16) swab samples were collected from ATM screens and keypads of eight commercial banks (namely Guaranty Trust, Fidelity, Union, First, Access, United Bank for Africa, Zenith and Keystone Banks respectively) situated within the study vicinity using a sterile cotton swabs soaked with sterile normal saline and immediately transported to the microbiology laboratory within sixty minutes of collection for bacteriological analysis to avoid drying of the samples. They were processed in the laboratory according to microbiological standard operating procedures under strict aseptic arena. The swab sticks were introduced onto suitable media.

\subsection{Isolation, Enumeration and Identification of Bacterial Isolates}

The swab sticks bearing the samples from the ATMs (Screens and Keypads) were dipped into test tubes containing sterile distilled water and agitated for five (5) minutes, after which samples were serially diluted to obtain $10^{-1}, 10^{-2}, 10^{-3}, 10^{-4}$, and $10^{-5}$ respectively. $1 \mathrm{ml}$ of $10^{-2}$ dilution series of the ATMs parts were inoculated into sterile Petri dishes in triplicates before appropriate media such as Nutrient agar (NA), Mannitol salt agar (MSA) and MacConkey agar (MCA) all of Hi media were dispensed into it to ascertain the total aerobic bacteria, Staphylococcus aureus and Coliform counts respectively. All inoculated plates were incubated at $37^{\circ} \mathrm{C}$ for $24 \mathrm{hrs}$, thereafter enumeration of colonies was done with the aid of the illuminated colony counter (Gallenkamp, Englang). The total aerobic plate count was ascertained by multiplying the mean viable, separated, visible and distinct colonies counts from the triplicate Petri dishes with the reciprocal of the dilution factor and the volume of inoculum used. This was expressed as colony forming unit per metre square $\left(\mathrm{cfu} / \mathrm{m}^{2}\right)$. Morphological traits of the colonies were checked, discrete colonies on the different media were isolated for subculturing onto other media to obtain axenic cultures, which were subsequently stored on Nutrient agar slants for later biochemical tests at $4{ }^{\circ} \mathrm{C}$. 


\subsubsection{Identification of Bacteria}

The isolated bacteria from the ATMs screens and keypads were identified by using their cultural and morphological characteristics on media. This was followed by microscopic investigation of their Gram reaction under the microscope. The cultural features examined included shape, elevation, surface edge and consistency. Physiological and biochemical tests were employed to confirm their identification [14].

\subsubsection{Statistical Analysis}

The mean and standard deviation of the experimental values obtained for total aerobic bacterial plate count, Escherichia coli and Staphylococcus aureus counts were calculated and also subjected to analysis of variance (ANOVA) using the SPSS software version 20 (IBM, USA) to ascertain whether significance difference existed among the groups.

\section{Results}

This study was done to investigate the quantity, variability assessment of bacterial cross pollution and Public Health hazards linked to users of Banks' Automated Teller Machine (ATM) in Ekpoma. Table 1 shows the numbers and location of samples collected. Table 2 represents the number of bacteria colonies counted on Nutrient agar (NA), Mannitol Salt agar (MSA) and Mac Conkey agar (MCA) for all the samples within the study arena. Table 3 represents the result of mean and standard deviation of the total aerobic bacteria, Staphylococcus aureus and Coliforms counts respectively. The total aerobic bacteria count (ABC) of the ATM samples from the various banks were high ranging from $9.0 \times$ $10^{3} \pm 2.65 \mathrm{cfu} / \mathrm{m}^{2}-1.92 \times 10^{4} \pm 3.61 \mathrm{cfu} / \mathrm{m}^{2}$ ATM keypads of Bank $B$ and $G$ had the highest bacteria load of $1.92 \times$ $10^{4} \pm 3.61 \mathrm{cfu} / \mathrm{m}^{2}$ respectively, while the ATM screen of Bank $\mathrm{F}$ had the lowest value of $9.0 \times 10^{3} \pm 2.65 \mathrm{cfu} / \mathrm{m}^{2}$. Highest Staphylococcus aureus count was noticed in Bank G ATM keypad with a value of $9.8 \times 10^{3} \pm 4.58 \mathrm{cfu} / \mathrm{m}^{2}$ while the lowest was detected in Bank A ATM screen with $3.5 \times$ $10^{3} \pm 1.73 \mathrm{cfu} / \mathrm{m}^{2}$. The coliforms counts ranged from $4.8 \times$ $10^{3} \pm 1.00 \mathrm{cfu} / \mathrm{m}^{2}$ to $1.08 \times 10^{4} \pm 2.00 \mathrm{cfu} / \mathrm{m}^{2}$ with the highest count observed in Bank G ATM keypad with a reading of $1.08 \times 10^{4} \pm 2.00 \mathrm{cfu} / \mathrm{m}^{2}$, while the least count was found in Bank F ATM screen with a value of $4.8 \times 10^{3} \pm 1.00 \mathrm{cfu} / \mathrm{m}^{2}$. Figure 1 shows the total percentage occurrence of bacterial isolates from the ATM keypads and screens across the eight (8) banks under examination.

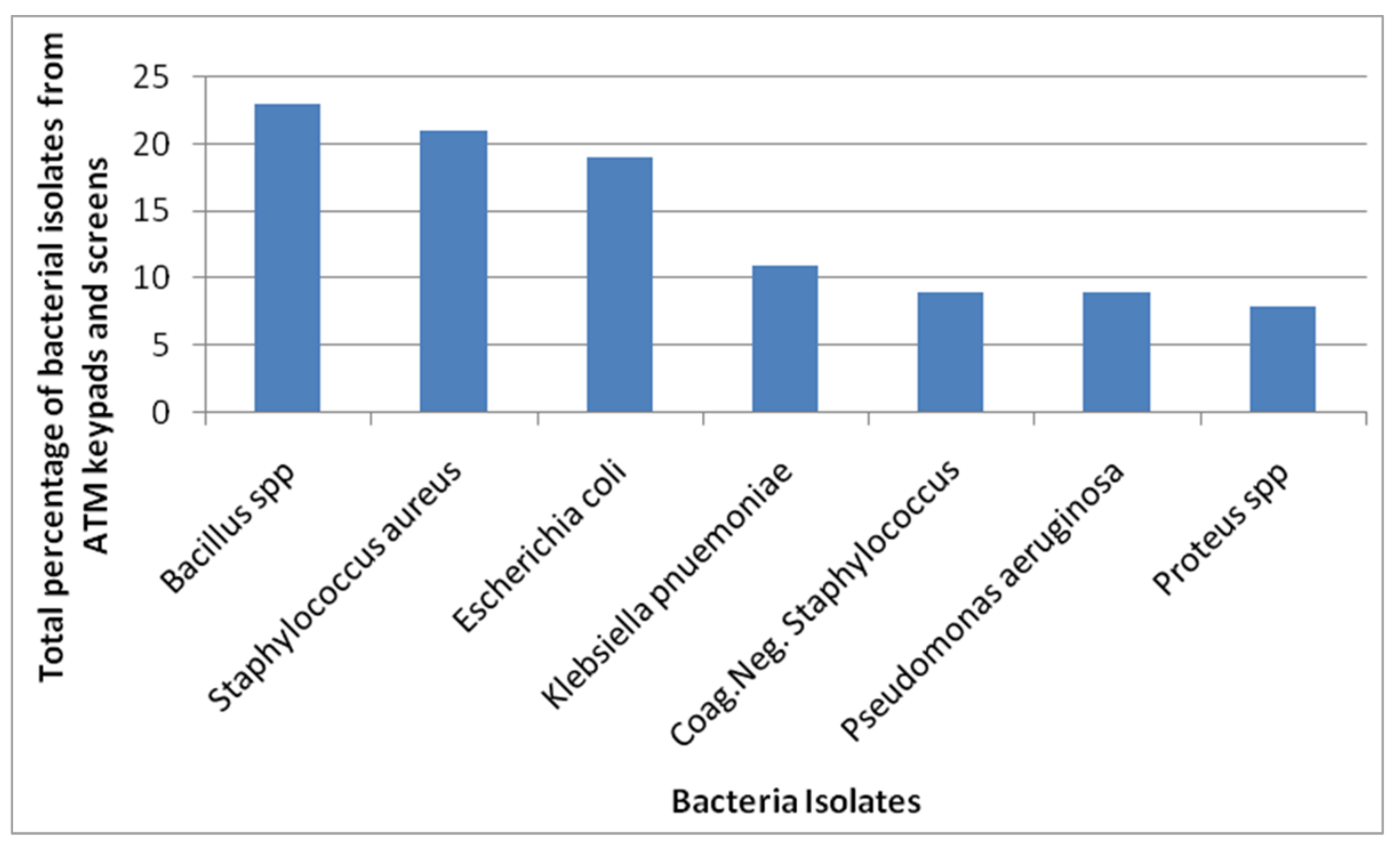

Figure 1. Total percentage occurrence of bacterial isolates from ATM keypads and screens.

Bacillus spp has the highest occurrence with a total of $23 \%$, Staphylococcus aureus has a total occurrence of $21 \%$, Eschericihia coli has a total presence of $19 \%$, total percentage occurrence for Klebsiella pneumonia is $11 \%$, Coagulase negative Staphylococcus spp and Pseudomonas aeruginosa total percentage of occurrence is $9 \%$ respectively,
Proteus spp had the least total occurrence of $8 \%$. Figure 2 represents the total number of bacterial isolates within the various banks. Bank A, B and $\mathrm{E}$ had $11 \%$, Bank $\mathrm{C}$ and $\mathrm{F}$ had $13 \%$, Bank D and $\mathrm{G}$ had 15\% while Bank $\mathrm{H}$ had the least total number of bacterial isolates of $5 \%$. 


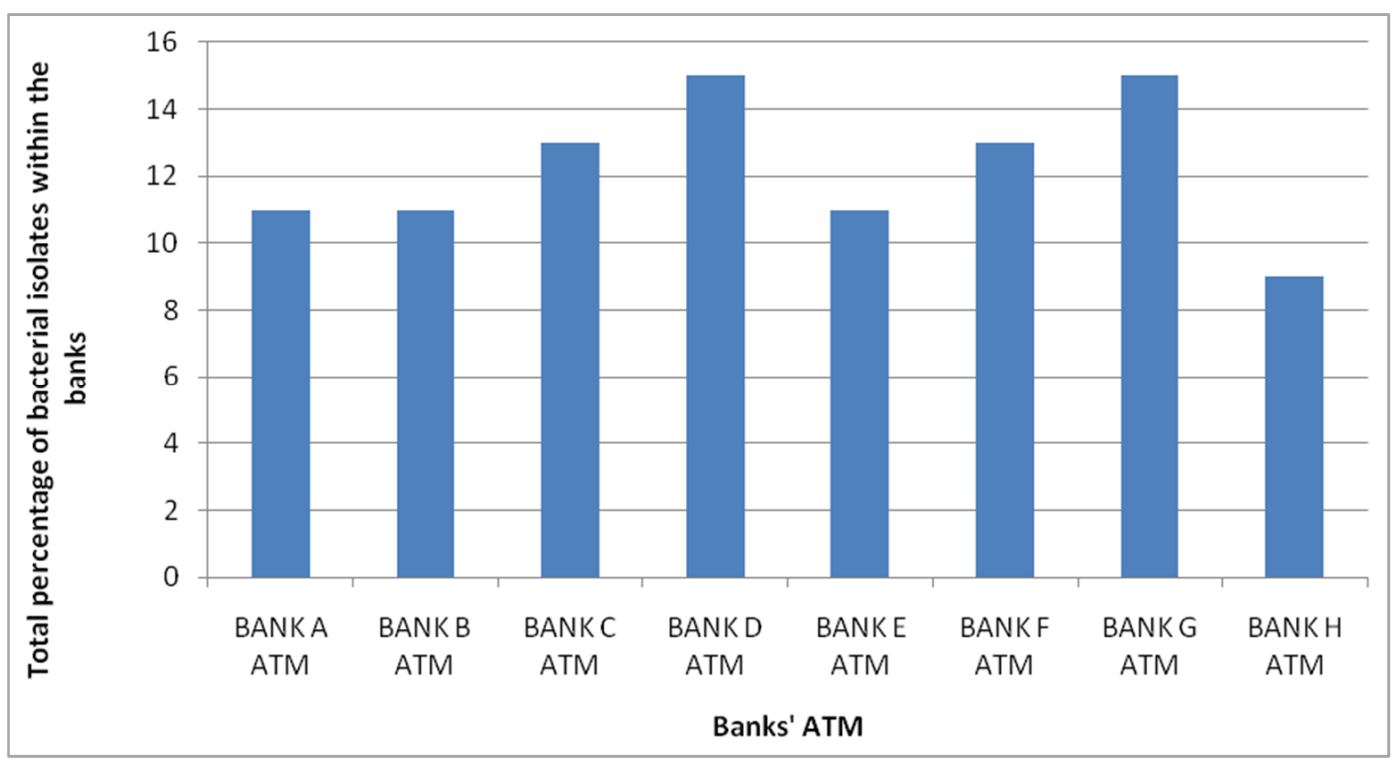

Figure 2. Total percentage of bacterial isolates within the Banks.

The bacteria implicated in the banks' ATM samples in this study were Escherichia coli, Bacillus spp, Klebsiella pnuemoniae, Staphylococcus aureus, Pseudomonas aeruginosa, Proteus spp and Coagulase negative
Staphylococcus spp (Table 4). There was no significant difference $(\mathrm{P}>0.05)$ in the total aerobic bacterial plate count, Escherichia coli and Staphylococcus aureus counts in the various banks' ATM keypads and screens (Table 5).

Table 1. Number of samples (ATM Keypads and Screens) collected from the various banks and their location.

\begin{tabular}{lllllllll}
\hline BANK & A & B & C & D & E & F & G & HOTAL \\
\hline Keypad & 1 & 1 & 1 & 1 & 1 & 1 & 1 & 1 \\
Screen & 1 & 1 & 1 & 1 & 1 & 1 & 1 \\
Total & 2 & 2 & 2 & 2 & 2 & 2 & 2 \\
\hline
\end{tabular}

Legend: A=Bank A ATM situated at Ihumudumu road.

$\mathrm{B}=$ Bank B ATM situated at Ihumudumu road.

C=Bank C ATM situated at Royal market road.

$\mathrm{D}=$ Bank D ATM situated at Royal market road.

E=Bank E ATM situated at Akhere lane.

$\mathrm{F}=$ Bank F ATM situated at Ukpenu road.

$\mathrm{G}=$ Bank G ATM situated at Ukpenu road.

$\mathrm{H}=$ Bank H ATM situated at Alli Square.

Table 2. Results of bacterial colonies count from the different Banks.

\begin{tabular}{lllllll}
\hline Banks & ATM Portions & $\begin{array}{l}\text { Aerobic plate count } \\
\text { (NA) }\end{array}$ & $\begin{array}{l}\text { S. aureus count } \\
\text { (MSA) }\end{array}$ & $\begin{array}{l}\text { Coliform counts } \\
\text { (MCA) }\end{array}$ & Volume of inoculum & $\begin{array}{l}\text { Dilution } \\
\text { factor }\end{array}$ \\
\hline A & Keypad & $188,189,187$ & $53,59,62$ & $79,85,85$ & $1 \mathrm{ml}$ & $10^{-2}$ \\
& Screen & $89,95,92$ & $33,36,36$ & $58,54,65$ & $1 \mathrm{ml}$ & $10^{-2}$ \\
B & Keypad & $188,193,195$ & $60,63,66$ & $100,102,104$ & $1 \mathrm{ml}$ & $10^{-2}$ \\
& Screen & $183,185,193$ & $69,71,76$ & $105,106,110$ & $1 \mathrm{ml}$ & $10^{-2}$ \\
C & Keypad & $101,104,110$ & $90,89,100$ & $101,102,97$ & $1 \mathrm{ml}$ & $10^{-2}$ \\
& Screen & 183,184185 & $80,81,88$ & $103,102,107$ & $1 \mathrm{ml}$ & $10^{-2}$ \\
D & Keypad & $105,107,115$ & $43,44,51$ & $83,84,85$ & $1 \mathrm{ml}$ & $10^{-2}$ \\
& Screen & $90,93,99$ & $38,35,44$ & $56,54,61$ & $1 \mathrm{ml}$ & $10^{-2}$ \\
E & Keypad & $169,170,171$ & $56,58,63$ & $90,92,97$ & $1 \mathrm{ml}$ & $10^{-2}$ \\
& Screen & $101,102,103$ & $47,48,52$ & $59,63,73$ & $1 \mathrm{ml}$ & $10^{-2}$ \\
F & Keypad & $180,179,184$ & $66,69,69$ & $59,58,60$ & $1 \mathrm{ml}$ & $10^{-2}$ \\
& Screen & $89,88,93$ & $69,71,76$ & $47,49,48$ & $1 \mathrm{ml}$ & $10^{-2}$ \\
G & Keypad & $189,191,196$ & $97,94,103$ & $106,108,110$ & $1 \mathrm{ml}$ & $10^{-2}$ \\
& Screen & $103,105,104$ & $77,79,78$ & $97,98,102$ & $1 \mathrm{ml}$ & $10^{-2}$ \\
H & Keypad & $159,157,164$ & $46,48,47$ & $62,63,67$ & $1 \mathrm{ml}$ & $10^{-2}$ \\
& Screen & $94,96,95$ & $41,40,39$ & $61,59,63$ & $1 \mathrm{ml}$ & $10^{-2}$ \\
\hline
\end{tabular}

Legend: NA=Nutrient Agar, MSA=Mannitol Salt Agar and MCA=MacConkey Agar. 
Table 3. Results of Mean and Standard Deviations of bacterial counts from the different Banks'ATM.

\begin{tabular}{lllll}
\hline Banks & ATM Portions & $\begin{array}{l}\text { Aerobic bacteria count (NA) } \\
\text { Mean } \pm \text { SD* }\end{array}$ & S. aureus count (MSA) Mean \pm SD* & $\begin{array}{l}\text { Coliform counts (MCA) } \\
\text { Mean } \pm \text { SD }^{*}\end{array}$ \\
\hline A & Keypad & $1.88 \times 10^{4} \pm 1.00$ & $5.8 \times 10^{3} \pm 4.58$ & $8.3 \times 10^{3} \pm 3.46$ \\
& Screen & $9.2 \times 10^{3} \pm 3.00$ & $3.5 \times 10^{3} \pm 1.73$ & $5.9 \times 10^{3} \pm 5.57$ \\
B & Keypad & $1.92 \times 10^{4} \pm 3.61$ & $6.3 \times 10^{3} \pm 3.00$ & $1.02 \times 10^{4} \pm 2.00$ \\
& Screen & $1.87 \times 10^{4} \pm 5.29$ & $7.2 \times 10^{3} \pm 3.61$ & $1.07 \times 10^{4} \pm 2.65$ \\
C & Keypad & $1.05 \times 10^{4} \pm 4.58$ & $9.3 \times 10^{3} \pm 6.08$ & $1.00 \times 10^{4} \pm 2.65$ \\
& Screen & $1.84 \times 10^{4} \pm 1.00$ & $8.3 \times 10^{3} \pm 4.36$ & $1.04 \times 10^{4} \pm 2.65$ \\
D & Keypad & $1.09 \times 10^{4} \pm 5.29$ & $4.6 \times 10^{3} \pm 4.36$ & $8.4 \times 10^{3} \pm 1.00$ \\
& Screen & $9.4 \times 10^{3} \pm 4.58$ & $3.9 \times 10^{3} \pm 4.58$ & $5.7 \times 10^{3} \pm 3.61$ \\
E & Keypad & $1.70 \times 10^{4} \pm 1.00$ & $5.9 \times 10^{3} \pm 3.61$ & $9.3 \times 10^{3} \pm 3.61$ \\
& Screen & $1.02 \times 10^{4} \pm 1.00$ & $4.9 \times 10^{3} \pm 2.65$ & $6.5 \times 10^{3} \pm 7.21$ \\
F & Keypad & $1.81 \times 10^{4} \pm 2.65$ & $6.8 \times 10^{3} \pm 1.73$ & $5.9 \times 10^{3} \pm 1.00$ \\
& Screen & $9.0 \times 10^{3} \pm 2.65$ & $7.2 \times 10^{3} \pm 3.61$ & $4.8 \times 10^{3} \pm 1.00$ \\
G & Keypad & $1.92 \times 10^{4} \pm 3.61$ & $9.8 \times 10^{3} \pm 4.58$ & $1.08 \times 10^{4} \pm 2.00$ \\
& Screen & $1.04 \times 10^{4} \pm 1.00$ & $7.8 \times 10^{3} \pm 1.00$ & $9.9 \times 10^{3} \pm 2.65$ \\
H & Keypad & $1.60 \times 10^{4} \pm 3.61$ & $4.7 \times 10^{3} \pm 1.00$ & $6.4 \times 10^{3} \pm 2.65$ \\
& Screen & $9.5 \times 10^{3} \pm 1.00$ & $4.0 \times 10^{3} \pm 1.00$ & $6.1 \times 10^{3} \pm 2.00$ \\
\hline
\end{tabular}

Values are presented as mean and standard deviation *SD: Standard Deviation.

Table 4. Bacterial isolates from the different Banks'ATM (Keypad and Screen).

\begin{tabular}{|c|c|c|}
\hline Banks & ATM Portion & Bacteria Isolated \\
\hline \multirow[t]{2}{*}{ A } & Keypad & Escherichia coli, Staphylococcus aureus and Bacillus spp \\
\hline & Screen & Staphylococcus aureus, Pseudomonas aeruginosa and Bacillus spp \\
\hline \multirow[t]{2}{*}{ B } & Keypad & Coagulase Negative Staphylococcus, Escherichia coli, Bacillus spp and Staphylococcus aureus \\
\hline & Screen & Bacillus spp and Staphylococcus aureus \\
\hline \multirow[t]{2}{*}{$\mathrm{C}$} & Keypad & Escherichia coli, Staphylococcus aureus, Klebsiella pnuemoniae, Proteus spp and P. aeruginosa \\
\hline & Screen & Coagulase Negative Staphylococcus and Bacillus spp \\
\hline \multirow[t]{2}{*}{$\mathrm{D}$} & Keypad & Escherichia coli, Staphylococcus aureus, Klebsiella pnuemoniae and Pseudomonas aeruginosa \\
\hline & Screen & Escherichia coli,, Bacillus cereus, Staphylococcus aureus and Coagulase Negative Staphylococcus \\
\hline \multirow[t]{2}{*}{$\mathrm{E}$} & Keypad & Escherichia coli, Staphylococcus aureus, Klebsiella pnuemoniae and Proteus spp \\
\hline & Screen & Klebsiella pnuemoniae and Bacillus spp \\
\hline \multirow[t]{2}{*}{$\mathrm{F}$} & Keypad & Bacillus spp, Proteus spp and Coagulase Negative Staphylococcus \\
\hline & Screen & Escherichia coli, Bacillus spp, Staphylococcus aureus and Coagulase Negative Staphylococcus \\
\hline \multirow[t]{2}{*}{ G } & Keypad & Escherichia coli, Staphylococcus aureus, Klebsiella pnuemoniae, Proteus spp and Bacillus spp \\
\hline & Screen & Bacillus spp, Escherichia coli and Pseudomonas aeruginosa. \\
\hline \multirow[t]{2}{*}{$\mathrm{H}$} & Keypad & Escherichia coli, Staphylococcus aureus and Bacillus spp \\
\hline & Screen & Pseudomonas aeruginosa and Klebsiella pnuemoniae. \\
\hline
\end{tabular}

Table 5. One-way AVONA statistics.

\begin{tabular}{lllll}
\hline Parameter & ATM Parts & F-Statistic & p- value & Remarks \\
\hline Total Bacteria counts & Keypads & 0.815 & 0.588 & NS \\
& Screens & 1.605 & 0.205 & NS \\
\hline
\end{tabular}

NS, not significant at $\mathrm{p}=0.05$.

\section{Discussion}

Microorganism can be transported from a person to another or from breatheless objects to hands and vice versa [15]. ATM machines are one of the most commonly touched surfaces today. This study depict that Automated Teller Machines (ATMs) used for dispensing money in the various banks examined with the study area were grossly contaminated with bacteria. Bank $D$ and $G$ had the most bacterial abundance while bank $\mathrm{H}$ has the least number of bacterial abundance. This could be ascribed to the large number of persons that use the ATMs as well as the proximity of the machines to densely populated places such as markets where series of persons trade on all kinds of foods, animals and plants products etc. Microbes from these products are transferred from the vast number of traders and other individuals who use the ATMs to withdraw money for business and personal financial dealings, thus raising the quantity and variability of microbes on the ATMs keypads and screen. Another contributing factor is the Location and closeness of these machines to the roads exposing them to dusts, rain and wind. The quantity and variability of the bacterial isolates varied within the ATM portions (keypads and screens) of the various banks assessed. The bacteria isolated were Escherichia coli, Bacillus spp, Klebsiella 
pnuemoniae, Staphylococcus aureus, Pseudomonas aeruginosa, Proteus spp and Coagulase negative Staphylococcus spp. This is liken to the discoveries of (Mbajiuka, 2015)[16]. Who also reported some of the organisms on the ATM sampled. Bacteria of the enterobacteriaceae family such as Escherichia coli, Klebsiella pnuemoniae and Proteus spp were found on the ATM parts, These bacteria are conventional flora of the gastro-intestinal pathways of humans and animals with some been virulent, thus resulting to diseases such as dysentery, nausea and diarrhoea and food poisoning in man. Unhygienic practices such as improper hand cleansing has been adduced as to why such organisms were isolated from the ATM machines under assessment.

Bacillus spp was the most prevalent bacteria isolated from the findings of this study. It is a rod shaped Gram positive motile bacterium. Some strains are detrimental to man while others are beneficial to animals as probiotics, and its high presence is correlated to the fact that they are ubiquitous in nature often found in raw foods, dust and soil with their spores surviving environmental changes, withstanding dry heat, cooking temperature, and certain chemical disinfectants for moderate periods. This finding is in line with the research done by Brooks et al., 2007 [17]. Who reported them to be found among the preponderating organisms from user hardware interface.

The isolation of species of Staphylococcus such as Staphylococcus aureus and coagulase negative Staphylococcus from some of the ATM sampled in this study is not surprising as they are known resident microflora of the skin [18]. Staphylococcus aureus is normally carried by $20-40 \%$ of healthy persons at any material time. They possess the enzyme coagulase needed to make blood clot. They are however the most medically important Staphylococcus pathogen causing boils, carbuncles, abscesses, wound infections and pneumonia. Coagulase negative Staphylococcus lack the enzyme coagulase thus increasing the blood clotting time. They are normally consider harmless when its remains exterior the body. However they can become virulent when present on the blood in high volume of individuals with compromise immune system, indwelling urinary catheters, central intravenous lines, prosthetic joints etc. The isolation of $S$. aureus agrees with the findings of Nwankwo and Afuruobi, 2015 [19]. Staphylococcus aureus is ubiquitous in nature which explains why it is usually frequent as a contaminant, as it can be easily discharged by several human activities including sneezing, talking, and contact with moist skin [20]. Also, airborne organisms can be transported from users to passerby.

Pseudomonas aeruginosa is well documented for their high pathogenicity, causing even death in some major outbreaks and infections [21]. Its has emerged as a vital pathogen in the last two decades often implicated in between $10 \%$ to $20 \%$ of infections in the hospitals. It is a common nosocomial contaminant which can be transferred to other electronic hardware devices, thus their prevalence in this study. Patients with weakened defense system with extended periods of hospitalization is at risk of developing infections such as dangerous external otitis, endophthalmitis, endocarditis, meningitis, pneumonia and septicemia. Vast microbial loads were observed from the findings of this study with higher number of different types of bacteria isolates and contamination exhibited in Bank ATM D and G and fewer numbers of microbes in Bank ATM H because of the high and few numbers of customers who patronize the facilities. This is in conformity with the findings of Baker and Bloomfield, 2000 [22]. Who reported high frequency of organisms in surfaces associated with densely populated public facilities and few numbers of microbes in less dense populated public utilities. One-way Anova revealed a no significant difference in the total aerobic bacterial plate count, Escherichia coli and Staphylococcus aureus counts in the various banks' ATM (keypads and screens) in respectively of the facilities placement and the number of users.

\section{Conclusion and Recommendation}

The findings from this study have revealed that the ATMs used in dishing out cash within the various banks in Ekpoma were grossly contaminated with different potentially virulent bacteria genera. They were fabricated to facilitate the difficulties associated with banking, they nurse more bacterial contaminants than other electronic hardware, this can be adduced to their physical design and wider surface area, in conjunction with their location in exposed places prone to wind, dust particles and rain. These devices are consequently potential routes for the dispersion of medically important pathogens via human hands. Public enlightenment is critical with regards to handling ready to eat foods after using these public cash dispensing machines, as some reports have revealed the deficiencies in the general public's knowhow with regards to hygienic food handling practices [23, 24]. The dispersal of infection can be disrupted by adequate hygienic exercises. Cleaning plans geared towards reducing the quantity and variability of these bacteria on automated teller machines should be designed using effective sanitizers, though it is obviously hard to fully eradicate all bacteria from the ATM surfaces. However sticking to hand hygiene, cleaning, disinfecting polluted environmental surfaces and ATM devices should be strictly complied with by all users and operators of such machines to reduce the likely hood of spreading contagious agents.

\section{Acknowledgements}

My profound gratitude goes to God almighty that over the years has preserved my life and gave me wisdom and understanding to put this work together. Special appreciation also goes to my Head of Department Dr. (Mrs.) Okwu Grace Ifeoma and the entire staff of Microbiology Department, Ambrose Alli University, Ekpoma, Edo State Nigeria.

\section{Conflicts of Interest}

The authors declare that they have no competing interests. 


\section{References}

[1] Schlichter, S. (2007). Using ATM's abroad.www.Travel Travel Tips -msnbc.com.

[2] Hone, K. S., Graham, R., Maguire, M. C., Baber, C. and Johnson, G. I. (2008): Speech technology for automatic teller machines: an investigation of user attitude and performance. Ergonomics, 41 (7): 962-981.

[3] World Health Organisation (2014). Fact sheets on Environmental Sanitation. Extracted from: www.who.int/water_sanitation_health/hygiene/emergencies/en vsanfactssheets, accessed on 20 September 2019.

[4] Sharma, A. and Dhanashree, B. (2011). Screening of currency in circulation for bacteriological contamination. Journal of Current Science, 100 (6): 822-825.

[5] Sharma, N. and Rathore, V. S. (2012). Analysis of Different Vulnerabilities in Auto Teller Machine Transactions, Journal of Global Research in Computer Science, 3 (3): 38-40.

[6] Adedoyin, A. B. (2019). A Study Investigating Bacterial Colonization on Automated Teller Machines in Ibadan Metropolis, South-West Nigeria. Acta Scientific Pharmaceutical Science, 3 (6): 119-132.

[7] Kramer, A., Schwebke, I. and Kampf, G. (2006). How long do nosocomial pathogens persist on inanimate surfaces? A systematic review. British Medical Centre on Infectious Diseases, 6: 130-135.

[8] Padma, S. R. (2014). Automated Teller Machines (ATMs). A "pathogen City"-surveillance report from locations in and around Madurai city, Tamil Nadu, India. International Journal of Public Health Science, 3: 51-56.

[9] Jerkovic-Mujkic, A., Besta, R. and Memisevic, iS. (2103). IBacterial contamination of public telephones in the down town area of Sarajevo. African Journal of Microbial Research, 7 (17): 1664-1667.

[10] Onuoha, S. C. and Kayode, F. (2014). Bacterial Contamination and Public Health Risk Associated with the user of Banks' Automated Teller Machines (ATMs) in Ebonyi State, Nigeria. American Journal of Public Health, 2 (2): 46-50.

[11] Okoro, J., Oloninefa, S. D., Ojonigu, A. F. And Sani, M. (2018). Assessment of some selected automated teller machines in Kaduna metropolis for pathogenic bacteria contamination. British Journal of Environmental Sciences, 6 (1): $19-35$.

[12] Reynolds, K. A., Watt, P. M., Boone, S. A. and Gerba, C. P. (2005). Occurrence of Bacteria and Biochemical markers on public surface. International Journal of Environmental Health Research, 15: 225-234.
[13] Okun, R. and Okosun, M. (1990). An Overview of the Esan West Local Government. The Journal for geographical placement for Ekpoma community, 15 (4): 259-265.

[14] Cheesbrough, M. (2010). District laboratory practice in tropical countries. 3rd edition, Cambridge, University Press, United Kingdom. 70-95: 143.

[15] Bray, R., Fraser, S., Dunlop, M., Paterson-Brown, S. and Gibb, A. (2007). Bacterial contamination of mobile communication devices in the operative environment. Journal of Hospital Infection, 66 (4): 397-398.

[16] Mbajiuka, C. (2015). Isolation and Identification of microorganisms associated with the use of automated teller machine (ATM) in Micheal Okpara University of Agriculture, Umudike and its environs. World Journal of Pharmaceutical Research, 4 (8): 85-99.

[17] Brooks, G. P., Carroll, K. C., Butel, J. S. and Morse, S. A. (2007). Microscopy and Stains, In: Jawetz, Melnick and Adelberg's Medical Microbiology. $4^{\text {th }}$ Ed. USA: McGrawHill: 700-701.

[18] Hardy, K. J., Oppenheim, B. A., Gossain, S., Gao, F. and Hawkey, P. M. (2006): Study of the Relationship between Environmental Contamination with Methicillin-Resistant Staphylococcus aureus (MRSA) and Patients' Acquistion of MRSA. Infectious Control of Hospital Epidemiology, 27 (2): $127-132$.

[19] Nwankwo, E. O., Afuruobi, H. C. (2015). Bacterial contamination of door handles. Nigeria Journal of Microbiology, 29: 3139- 3147.

[20] Itah, A. T. and Ben, A. E. (2004). Incidence of enteric bacteria and Staphylococcus aureus in day care centers in Akwa-Ibom state, Nigeria. Southeast Asian Journal of Tropical Medicine and Public Health, 35 (1): 202-209.

[21] Mead, P. S., Slutcsker, L., Dietz, V., McCaig, L. F., Bresee, J. S., Shapiro, C., Griffin, P. M. and Tauxe, R. V. (1999). FoodRelated Illness and Death in the United States. Emerging Infectious Diseases 5 (5): 607-625.

[22] Baker, J. and Bloomfield, S. F. (2000). Survival of salmonella in bathroom and toilet in homes. Journal of Applied Microbiology, 89: 137-144.

[23] Osatohanmwen, O., Okwu, G. I., Orobator, O. N. and Idiakheua, O. D. (2019). Assessing the bacteriological quality of some cooked and fried ready to eat street foods vended in Ekpoma, Edo State-Nigeria: Public Health Implications. The International Journal of Engineering and Science, 8 (11): 31-41.

[24] Van Asselt, E., Fischer, A., de Jong, A. E. I., Nauta, M. J. and de Jonge, R. (2009). Cooking practices in the kitchenobserved versus predicted behaviour. Risk Analysis, 29 (4): 533-540. 